\title{
Gully Erosion Study and Control: A Case Study of Queen Ede Gully in Benin City
}

\author{
Jacob O. Ehiorobo and Roland O. Ogirigbo \\ Department of Civil Engineering, Faculty of Engineering, University of Benin, Benin 300283, Nigeria
}

\begin{abstract}
This paper presents findings from studies carried out on the Queen Ede gully erosion site in Benin City, in the south-southern zone of Nigeria. The studies involved detailed topographical, geotechnical, meteorological and hydrological data acquisition. The data were processed and analyzed to determine catchment size, gully morphology, soil characteristics, rainfall pattern and hydrological pattern. These were then interpreted and used to determine the method of control to be adopted. The adopted control measures is a combination of structural and non-structural methods. The structural method involved the use of gully control structures to divert the runoff entering the gully from the head, while the non-structural method involved the use of boulders and vegetation to stabilize the gully walls around the head region.
\end{abstract}

Key words: Queen Ede gully, gully erosion, catchment, control structures.

\section{Introduction}

Gully erosion is an enormous type of environmental degradation which results in loss of valuable land used for agricultural, domestic, industrial and aesthetic purposes, as well as loss of property and even human lives [1]. It is formed as a result of water moving in rills, which concentrate to form larger channels. When rill erosion can no longer be repaired by merely tilling or disking, it is defined as gully erosion.

Generally, gully erosion occurs when runoff concentrates and flows at a velocity sufficient to detach and transport soil particles. In Nigeria, high land use pressure particularly in the south-east and south-south regions render the landscape more vulnerable to gully erosion. Land use changes have also caused the development of bank gullies along some river banks [2]. A recent study conducted in the south-eastern parts of Nigeria, showed that the primary causes of gully erosion in this region is as a result of roads lacking

Corresponding author: Jacob O. Ehiorobo, Ph.D., research fields: GNSS and geodetic positioning, deformation surveys and analysis, engineering and construction surveys and analysis, engineering and construction surveys, remote sensing, GIS, water resources modeling and environmental hazards analysis. E-mail: jeffa_geos@yahoo.com. proper drainage, unguided cultivations, and indiscriminate channelling of flood water on sloped terrain [3]. Also, changes in drainage pattern associated with urbanization can give rise to the formation of gullies especially where illegal settlements exist.

Gully erosion is the most destructive form of erosion as it destroys the soil structure, damage farm lands, destroy infrastructure, alter transportation corridors and lower water tables [4]. According to Ref. [5], the formation of gullies in the south-eastern part of Nigeria has become one of the greatest environmental disasters facing many towns and villages, as many agricultural lands have become unsuitable for cultivation and hundreds of people have had to relocate. Efforts are however being made to control some of these gullies as reported in Ref. [6].

A study conducted by Poesen [7] stated that soil shear strength at saturation of various soil horizons is a good indicator of their resistance against concentrated flow erosion. In Ezezika and Adetona [3], it was concluded that most of the gullies in the south-eastern part of Nigeria can be prevented from expanding by embarking on enhanced public awareness programs and better land management practices. While these 
practices can prevent the formation of future gullies, they are insufficient to control the huge gully erosion sites already existing.

Apart from the south-eastern parts of Nigeria, gully erosion still plagues other areas like the south-southern regions where Edo state is located. In order to adequately address the problems associated with gully erosion in this region, proper studies would have to be carried out to determine the topographical, geological, geotechnical, meteorological and hydrological characteristics of gullies in the region. On the gullies in this region, very little research have been done on the state of the gullies, the processes involved and control measures (both temporary and long-term) that can be put in place to ensure that the growth of the gullies are investigated.

It is to be noted that despite several case studies reported in literature, there is still the need for more research on the effectiveness and cost-efficiency of gully prevention and control measures. This is because, the effectiveness of many of these control measures depends on local conditions. For instance, it was reported that stabilizing a bank gully head in central Belgium with rock plug did not work in loess-derived soils and an alternative technique with geo-membranes had to be developed $[8,9]$.

This paper presents the findings from studies carried out on the Queen Ede gully erosion site in Benin City (south-south zone of Nigeria), and the solution adopted to prevent further growth and expansion of the gully by applying both structural and non-structural measures.

\section{Methodology}

\subsection{The Study Area}

The Queen Ede gully erosion site is located in Benin City, the capital city of Edo state in Nigeria. It lies within the UTM (Universal Traverse Mercator) zone 31 and is bounded by UTM coordinates $700,800 \mathrm{mN}$ to $702,500 \mathrm{mN}$ and $795,800 \mathrm{mE}$ to $796,000 \mathrm{mE}$. The gully runs down to the Ikpoba River in a south eastern direction, covering a total land area of $59,250.099 \mathrm{~m}^{2}$, with a perimeter of $2,219 \mathrm{~m}$.

The study area lies within the tropical rain forest zone and is characterized by annual rainfall ranging from $1,558.1 \mathrm{~mm}$ in 2001 to $2,618.3 \mathrm{~mm}$ in 2010. The elevation of the study area ranges from $16 \mathrm{~m}$ to $110 \mathrm{~m}$ above mean sea level. The location plan of the queen Ede gully erosion site in Benin City is shown in Fig. 1.

\subsection{Causes of Gully Erosion Problem and Previous Efforts at Rehabilitation}

The Queen Ede gully is believed to have started sometime in the 1990s, as a result of the abrupt termination of the outlet drain from the Benin-Agbor highway around the current location of the gully. Additionally, the runoff for the steep slope from streets within the upland catchment area contributed largely to the formation of the gully. For instance, there are four $900 \mathrm{~mm}$ diameter culverts under the Benin-Agbor highway, which carry the storm discharge from the neighbouring streets located around the gully head to two catch pits located on the opposite side of the highway. An assessment of the catch pits indicated that they are inadequate in size compared to the volume of storm runoff they receive at a time and therefore they can not serve the purpose for which they were constructed.

Efforts have been made in recent years by both the State and Federal Government to arrest the acceleration of the erosive action of the storm water in the area but these have not succeeded. Even recently, the local residents constructed a local earth channel to divert the storm runoff coming towards the gully from the streets within the upland catchment area, but this resulted in creating a secondary gully at the gully head.

\subsection{Field Survey Measurements}

Field reconnaissance survey was carried out using handheld Garmin 76 GPS, to capture key coordinates. Three control points were established at some distance on stable ground from the gully head by method of 


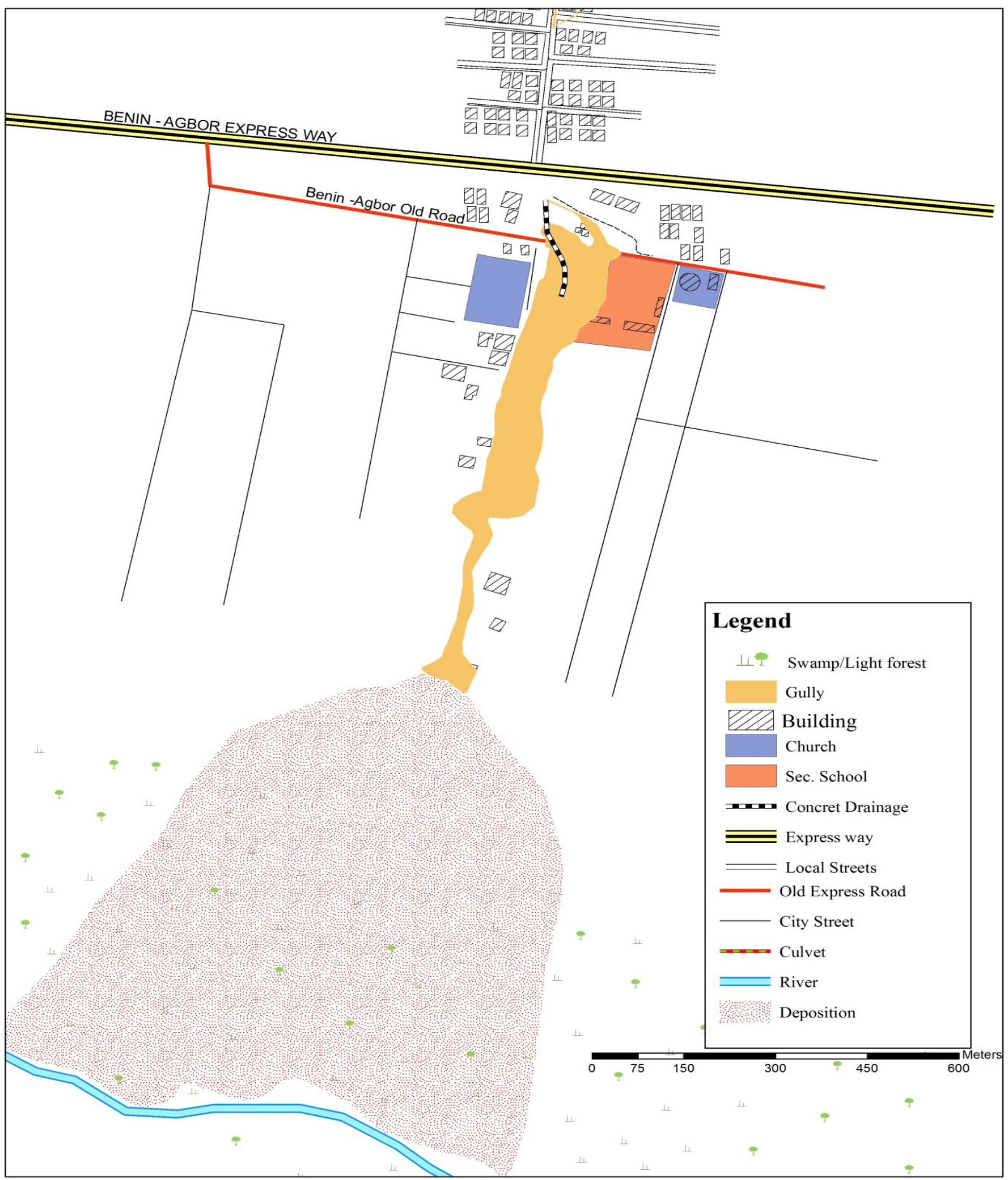

Fig. 1 Location of Queen Ede gully erosion site in Benin City.

Differential GPS. Leica Total Station instrument was then used for detailed surveys within the catchment basin to capture both the primary gully at Queen Ede and the other secondary gullies along Edebor and Pohgah streets.
Measurements were carried out to obtain the cross section of the gully and the topographical profile along the axis of the main gully channel from the head to the terminal point at Ikpoba River.

Total station measurements were collected at $1 \mathrm{~cm}$ 
level resolution to capture break in slopes and other topographic features necessary for producing DEM (digital elevation models) and to determine various morphological parameters such as width, depth, volume of soil loss, etc..

High resolution Ikono Imagery was acquired for the study area in order to measure and monitor the extent of the land area at risk, land use pattern, delineation of the catchment basin and analysis of infrastructure at risk or endangered by the gully. The topographical map of the Queen Ede gully erosion site is shown in Fig. 2. TIN (Triangulated Irregular Network) model of the gully site is shown in Fig. 3a while SPOT satellite image map of the site is shown in Fig. $3 b$.

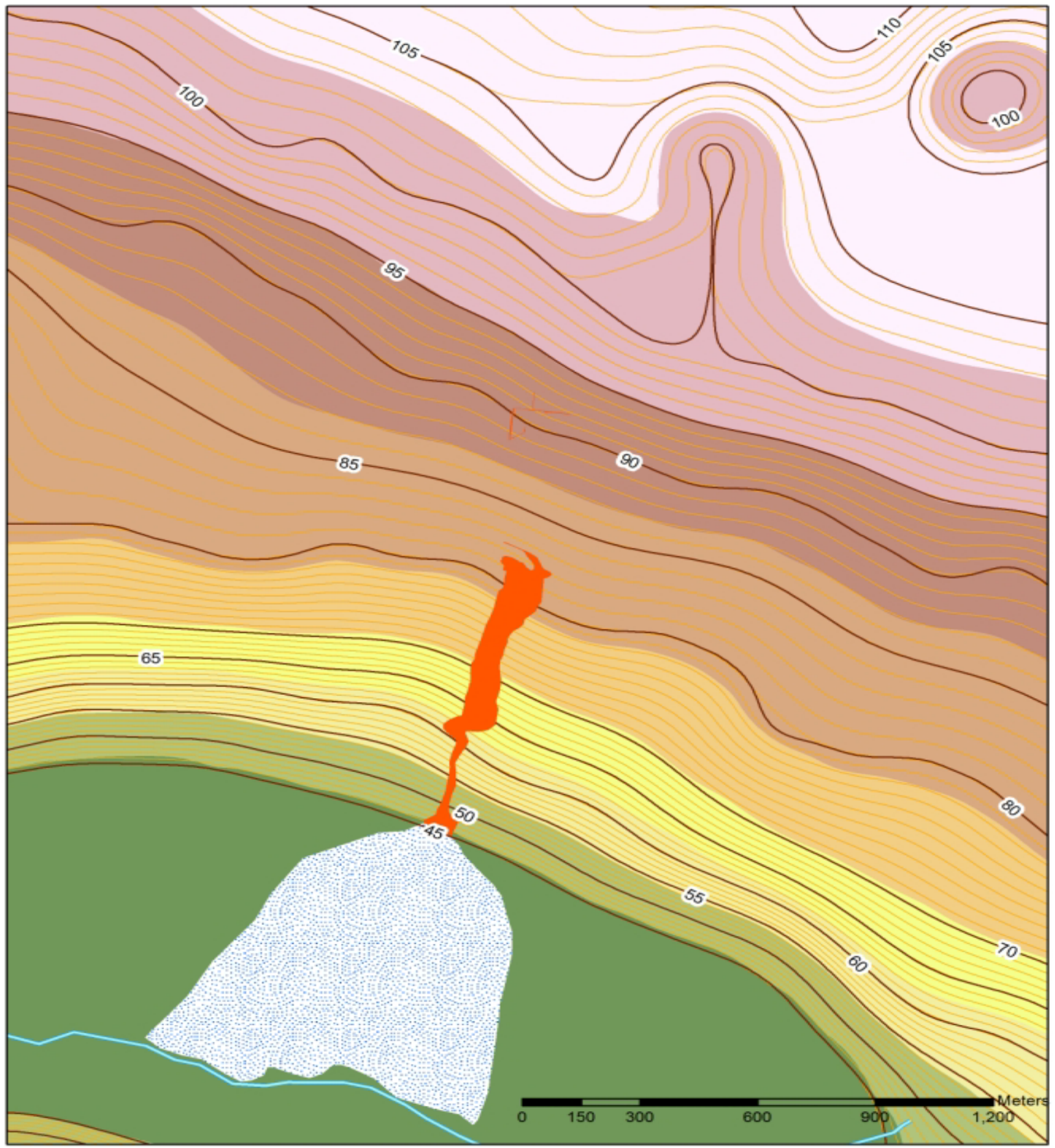

Fig. 2 Topographical map of Queen Ede gully and its catchment basin. 


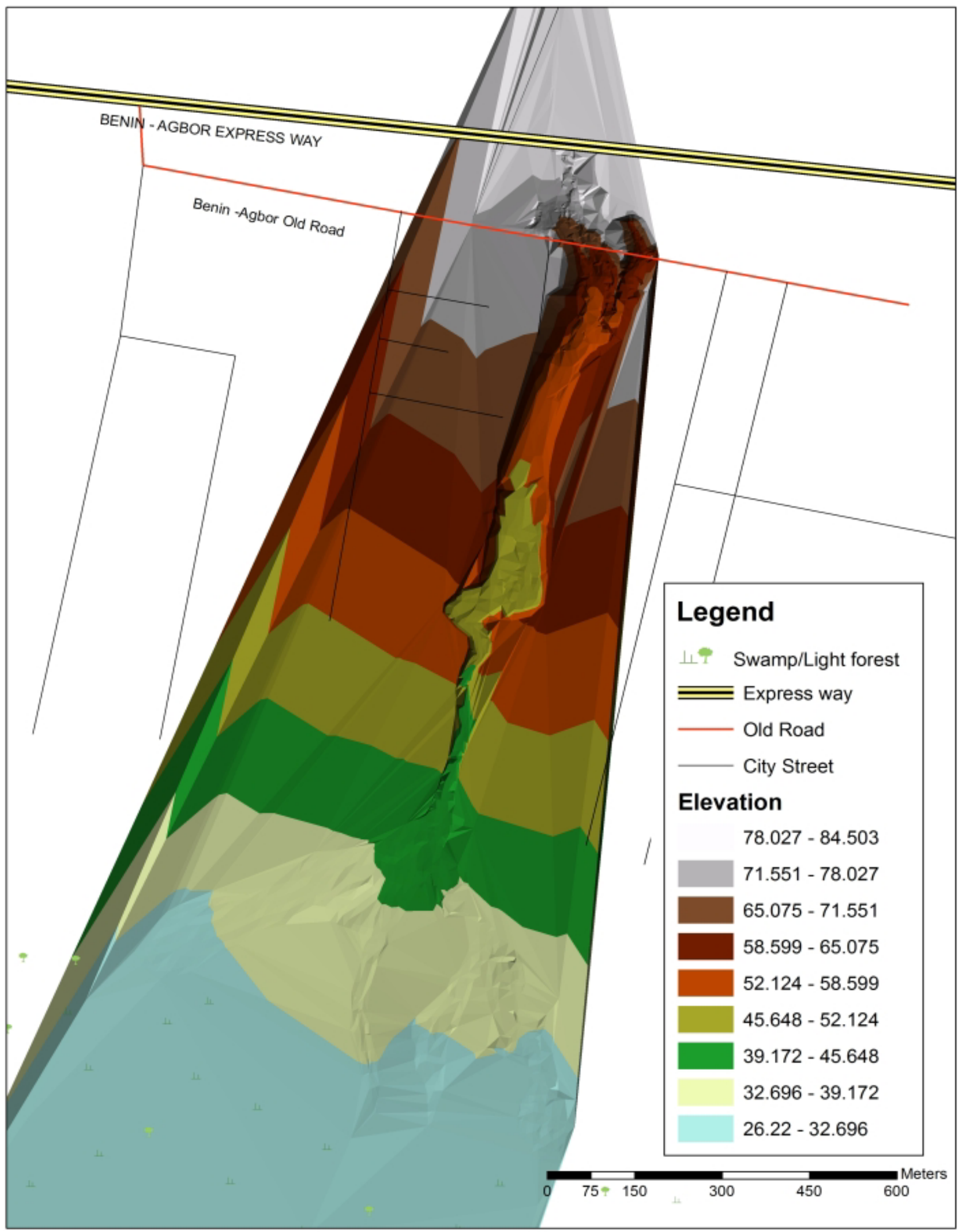

(a) 


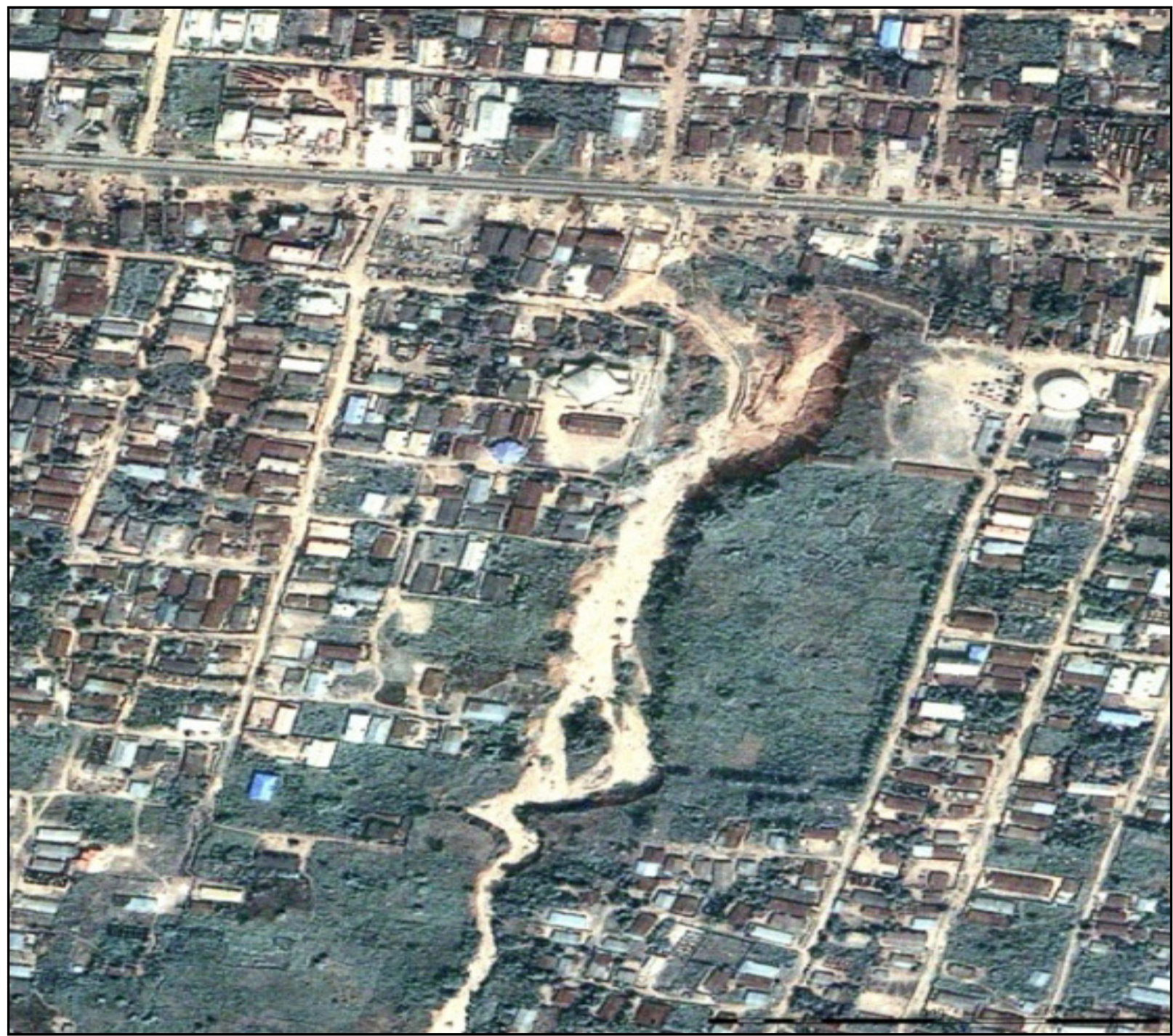

(b)

Fig. 3 The gully: (a) TIN (triangulated irregular network) model of the gully; (b) Ikono imagery of gully.

\subsection{Geotechnical Investigation}

Soil samples were collected from gully cross section along the bed and walls at specific locations and taken to the laboratory for testing and analysis. The tests carried out included natural moisture content, Atterberg limit tests, specific gravity tests, gradation, California Bearing Ratio tests, compaction tests, U-U triaxial and direct shear tests.

\subsection{Hydrological Studies}

Nigeria receives rainfall from the south westerlies which invade the country from the Gulf of Guinea
Coast. The moist air stream is overlain by the north east trade wind which originates from the Sahara, which is dry and dusty. The zone where these two air masses meet is a zone of moisture discontinuity and it is referred to as the ITD (inter tropical discontinuity). The rainfall producing system for Nigeria is a function of the migration pattern of the ITD.

Meteorological data have shown that the rainfall pattern in Nigeria have changed in the past decades, due to climate changes caused primarily by the effects of global warming. For example, the rainy season for the year 2012 began in late January, as against the usual periods of March and April. The monthly rainfall 
distribution for 2001-2010 was obtained from Benin meteorological station.

Using a design period of $2,5,10,25,50$ and 100 years duration, respectively, IDF (intensity duration frequency) curves were prepared for the study area.

Once the catchment basin has been delineated, rainfall intensity for the study area was computed using rainfall duration, equal to the time of concentration $\left(T_{C}\right)$, where, $T_{C}=\frac{0.195 L^{0.77}}{S^{0.385}}$, in minute [1].

\section{Data Processing and Results}

Spot elevation along with points coordinates were obtained from the Total Station instrument using the in-built software of the instrument.

Based on the points coordinates, morphological cross sections were obtained at $20 \mathrm{~m}$ interval. Other morphological parameters were calculated including length, width, depth and areas. The morphological parameters are shown in Tables 1 and 2 .

Using arc GIS 9.2 software, DEMs (digital elevation models) along with contours were plotted. This was then superimposed on the Ikono Imagery for catchment basin delineation and analysis.

Also cross sections were plotted at $20 \mathrm{~m}$ interval and bed profile from the head to the point of discharge. These are shown in Fig. 4, Figs. 5a and 5b, respectively.

The results of the soil tests from samples taken from both the gully bed and gully walls revealed that:

- The soil's specific gravity ranged from 2.37-2.66;

- More than $37.69 \%$ of the samples passed through Sieve No. $0.075 \mathrm{~mm}$;

- Liquid limit ranged from 27.71\%-3.55\%, plasticity limit $(10.39 \%-27.04 \%)$, plasticity index (13.11\%-49.8\%);

- Maximum dry density ranged from 1.19-1.87 $\mathrm{g} / \mathrm{cm}^{2}$;

- Angle of internal friction, $\varnothing=15^{\circ}$ and cohesion, $C$ $=2 \mathrm{kN} / \mathrm{m}^{2}$;

- CBR (California bearing ratio) values were very low (less than 5\%) for both soaked and unsoaked.

The monthly rainfall for 2001-2010 is presented in Table 3 and Fig. 6. Using Eq. (1), the time of concentration was computed to be equal to $34 \mathrm{~min}$. This is the time required to move surface runoff from the remotest point of the catchment basin to its outlet.

Rainfall Intensity Duration Curve was used estimate the effect of rain drop on gully wall and gully head erosion at the site (Table 3 and Fig. 6)

\section{Analysis and Discussion}

From Tables 1 and 2, the maximum width of the gully as in January 2012 was $112 \mathrm{~m}$ and the minimum width was $15.6 \mathrm{~m}$. The maximum depth was $16.4 \mathrm{~m}$ and the minimum depth was $0.4 \mathrm{~m}$. The WDR (width to depth ratio) varied from 2 to 42 . The volume of soil

Table 1 Morphological parameters of Queen Ede Gully as at January 2012.

\begin{tabular}{lccccc}
\hline Chainage $(\mathrm{m})$ & Top width, $B(\mathrm{~m})$ & Depth, $D(\mathrm{~m})$ & BDR & Cross sectional area, $A\left(\mathrm{~m}^{2}\right)$ & Cumulative volume, $V\left(\mathrm{~m}^{3}\right)$ \\
\hline $00+000$ & 15.604 & 0.374 & 42 & 3,510 & 0.000 \\
$00+100$ & 101.218 & 9.155 & 11 & 431,335 & $25,544.340$ \\
$00+200$ & 74.184 & 12.394 & 6 & 709,756 & $77,353.480$ \\
$00+300$ & 31.752 & 8.432 & 4 & 213,881 & $118,422.800$ \\
$00+400$ & 56.205 & 8.981 & 6 & 381,768 & $144,309.500$ \\
$00+500$ & 70.000 & 16.378 & 4 & 841,278 & $227,958.000$ \\
$00+600$ & 112.000 & 13.409 & 8 & 970,039 & $314,372.000$ \\
$00+700$ & 17.363 & 9.854 & 2 & 128,751 & $344,273.800$ \\
$00+800$ & 19.365 & 7.780 & 2.5 & 127,897 & $354,944.560$ \\
$00+900$ & 77.226 & 3.890 & 20 & 196,260 & $368,975.840$ \\
$00+960$ & 40.815 & 4.480 & 9 & 85,271 & $393,069.580$ \\
\hline
\end{tabular}




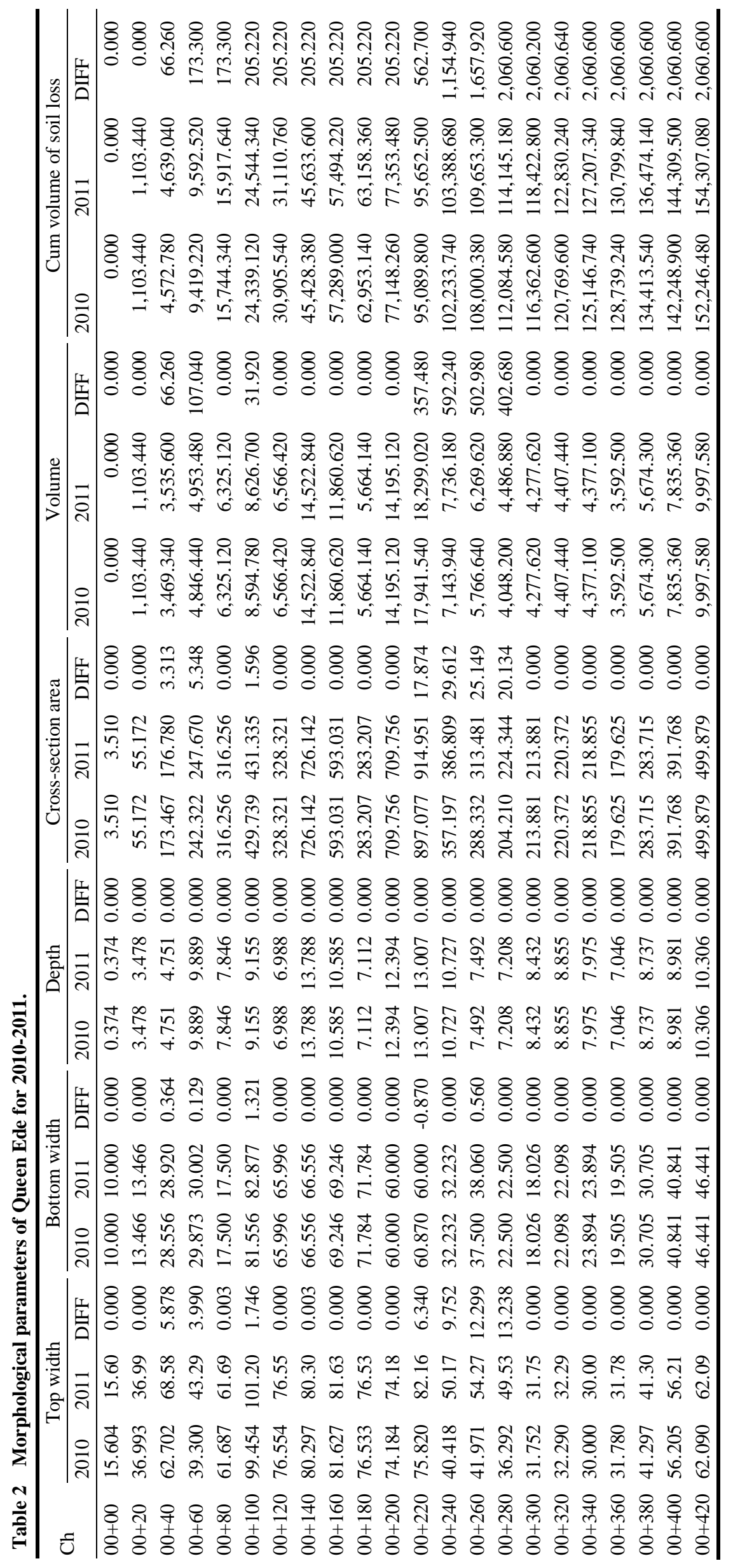




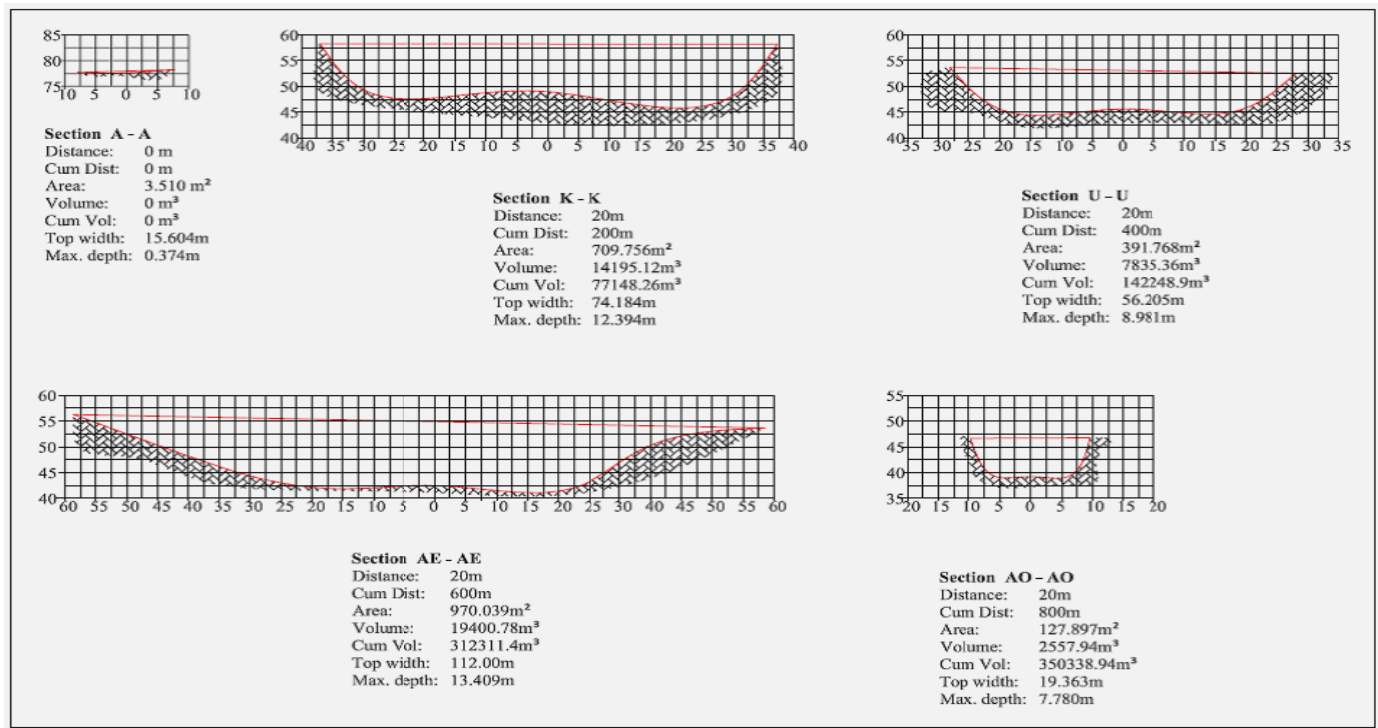

Fig. 4 Cross sections at $0 \mathrm{~m}, 200 \mathrm{~m}, 400 \mathrm{~m}, 600 \mathrm{~m}$ and $800 \mathrm{~m}$.

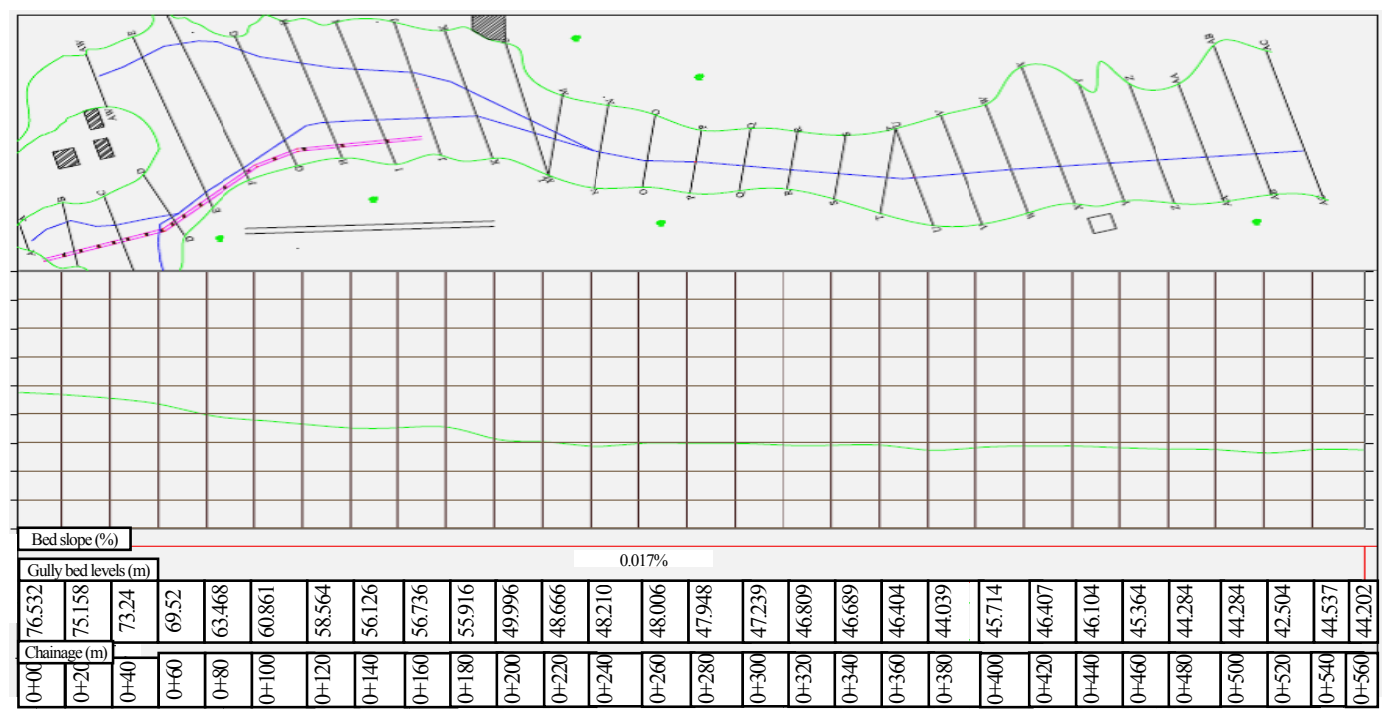

(a)

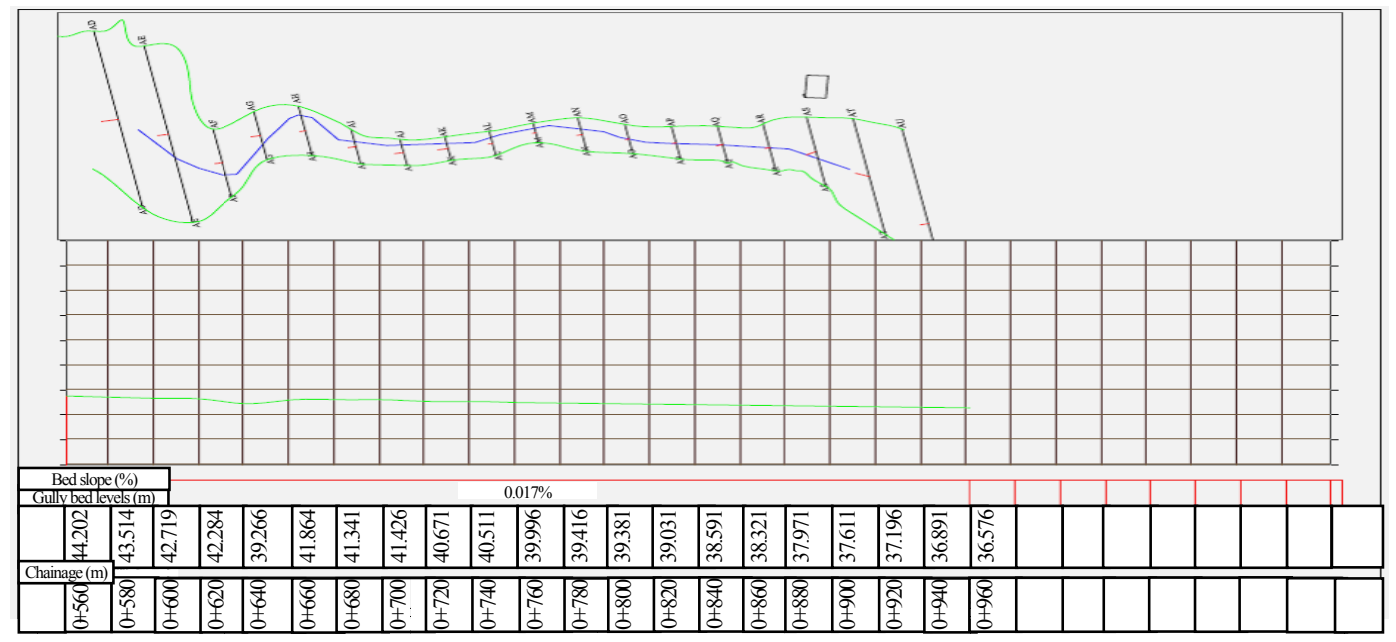

(b)

Fig. 5 Gully bed profile: (a) $0 \mathrm{~m}$ to $560 \mathrm{~m}$; (b) $560 \mathrm{~m}$ to $960 \mathrm{~m}$. 
表

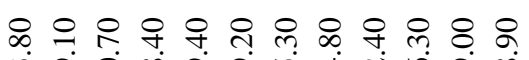

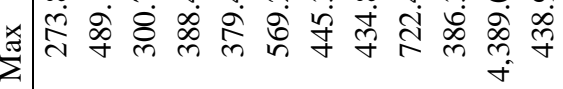

के थि

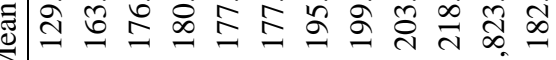

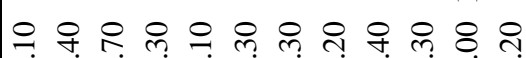

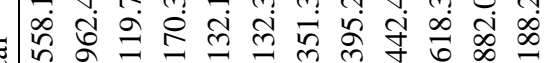

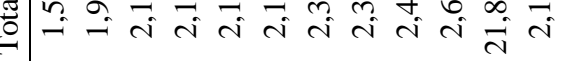

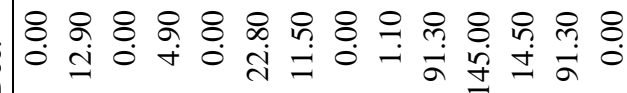

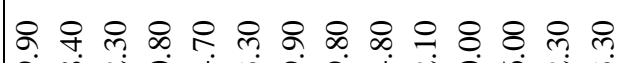

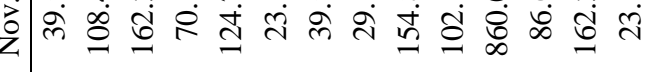

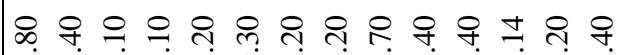

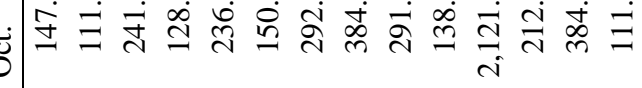

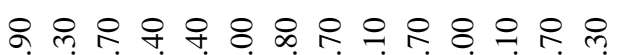

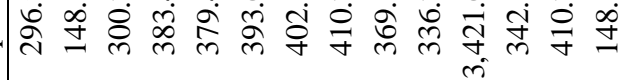

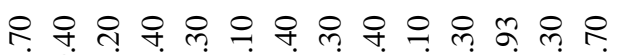

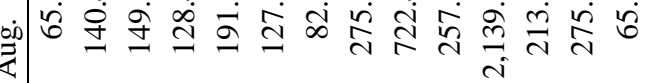

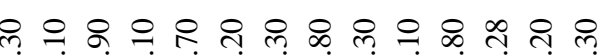

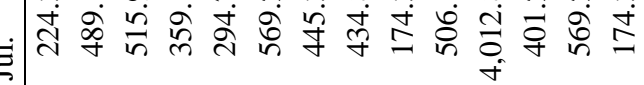

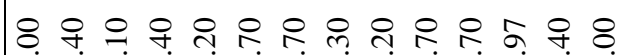

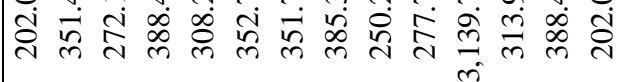

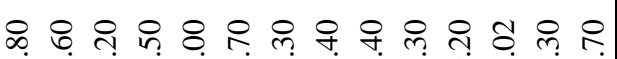
光

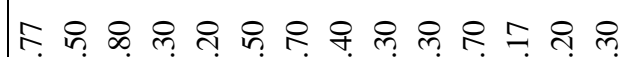

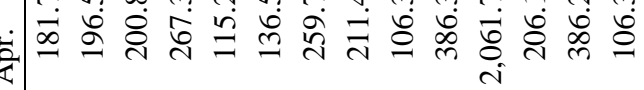

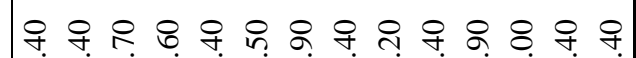

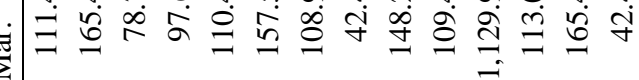

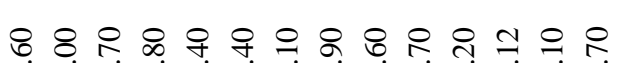

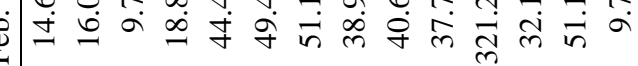

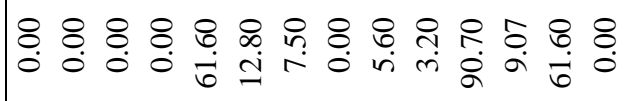

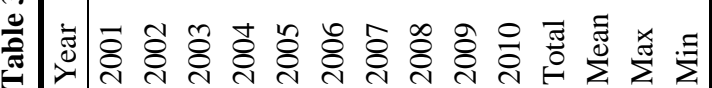




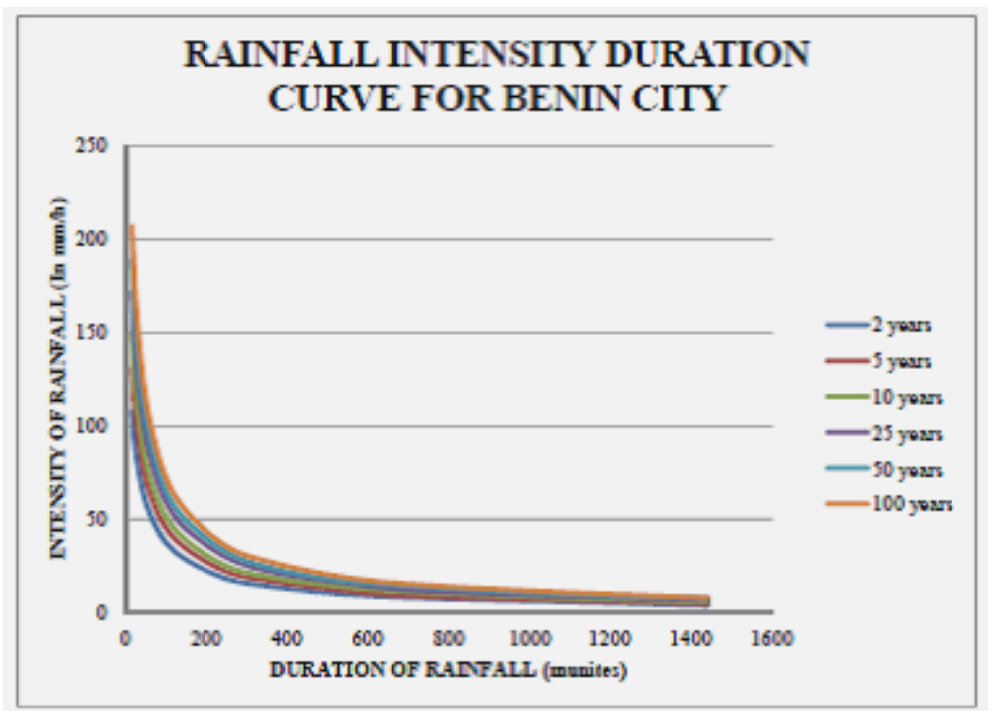

Fig. 6 Rainfall IDF (intensity duration frequency) curve for Benin City.

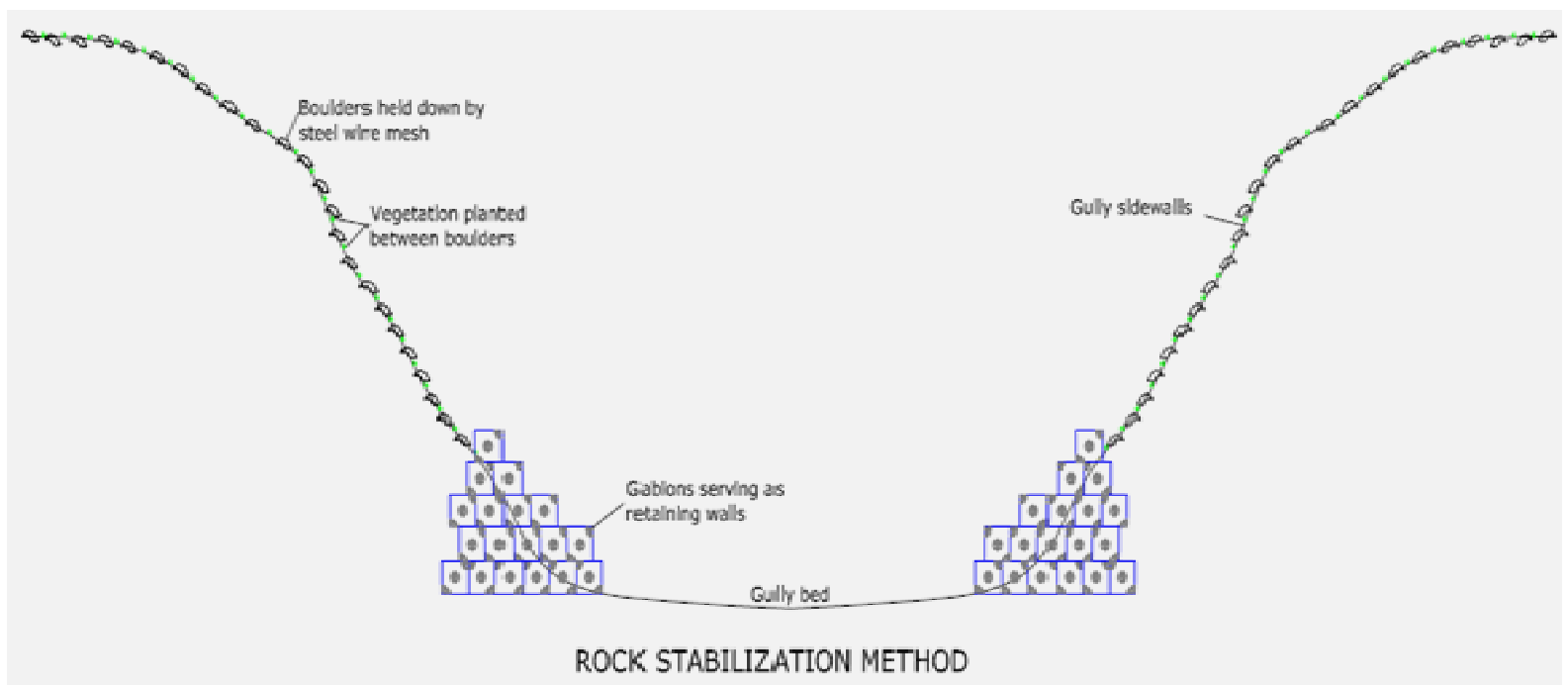

Fig. 7 Slope stabilization technique.

loss was estimated to be $393,069.580 \mathrm{~m}^{3}$ over a surface area of $126,480 \mathrm{~m}^{2}$ which is equivalent to $3.108 \mathrm{~m}^{3} / \mathrm{m}^{2}$.

Recent results (Table 1) showed that under-cutting and collapse of gully walls continue to occur around the gully head as a result of active erosive action in this area caused by the storm runoff.

The geotechnical investigation results revealed that the soil is silty clay. Erosion in this type of soil is irreversible and it is reasonable to assume that there is a tendency for widening of gully to occur due to wall slumping especially during the period characterized by high rainfall (from May-September).

Arising from the above, the following control measures were proposed for the Queen Ede gully erosion:

- Redesign and provide adequate drainage system that will be able to carry all the storm runoff from the catchment area, and channel them away from the gully to appropriate discharge points;

- Implement appropriate reclamation and stabilization of the gully head to prevent further head cutting;

- Provide check dams along the gully bed to control movement and transportation of eroded soils by reducing high runoff and flow velocities along the gully bed and thereby protecting the bed from incision and deepening; 
- Provide adequate slope stabilization along the gully walls using gabions as retaining walls at the base and rock boulders placed on the gully walls, which have been trimmed to appropriate slopes. In between these boulders are planted vetiver grass and bamboo trees with firm roots to hold the soil in place against erosion. The boulders are held down by steel meshes, which will later be removed as the grasses and trees begin to grow. Typical cross section of the proposed method is shown in Fig. 7.

\section{Conclusions}

Based on the findings from the studies conducted, the following conclusions were drawn:

- The likely cause of this gully is as a result of the river bank eating back into the land, and this has been accelerated by the way the accumulated runoff from the catchment enters into the river;

- The recent abrupt growth and expansion of the gully can be attributed to the change in the rainfall pattern in the region, which has been caused by climate change resulting from global warming;

- Apart from the head region of the gully, other regions such as the middle and the tail regions have already stabilized. Thus, only the head region is active;

- The results from the geotechnical studies conducted on the soil showed that the soil is susceptible to water erosion;

- The existing drainage facilities are inadequate to contain the runoff coming from the catchment;

- Control measures such as slope stabilization for the gully walls around the head region, redesigning and upgrading of the existing drainage system, provision of gully control structures at the head region, and provision of check dams at specific intervals along the gully bed, can be used to prevent the gully from expanding.

\section{References}

[1] I.I. Obiadi, C.M. Nwosu, N.E. Ajaegwu, E.K. Anakwuba, N.E. Onuigbo, E.O. Akponomu, et al., Gully erosion in Anambra State, south east Nigeria: Issues and solution, International Journal of Environmental Sciences 2 (2) (2011) 795-804

[2] J.O. Ehiorobo, O.C. Izinyon, Measurement and documentation for flood and erosion monitoring and control in the Niger Delta States of Nigeria, www.fig.net/pub/fig2011 (accessed Jan. 1, 2013).

[3] O.C. Ezezika, O. Adetona, Resolving the gully erosion problem in south-eastern Nigeria: Innovation through public awareness and community-based approaches, Journal of Soil Science and Environmental Management 2 (10) (2011) 286-291.

[4] C. Valentin, J. Poesen, L. Young, Gully erosion: Impacts, factors and control, Catena 63 (2005) 132-153.

[5] K.O. Adekalu, I.A. Olorunfemi, J.A. Osunbitan, Grass mulching effect on infiltration, surface runoff and soil loss of three agricultural soils in Nigeria, Bioresource Technology 98 (4) (2007) 912-917.

[6] S.C. Teme, P.O. Youdeowei, Geotechnical investigations for design of foundations for erosion and flood control structures at Unwana Beach, Afikpo, Ebonyi state, South-Eastern Nigeria, in: Proceedings of 5th International Conference on Case Histories in Geotechnical Engineering, New York, USA, Apr. 13-17, 2004.

[7] J. Poesen, Gully topology and gully control measures in the European loess belt, in: S. Wicherek (Ed.), Farm Land Erosion in Temperate Plains and Hills, Elsevier, Amsterdam, 1993, pp. 221-239.

[8] J. Poessen, J. Ngchtergaele, G. Verstraeten, C. Valentin, Gully erosion and environmental change: Importance and research needs, Catena 50 (2003) 91-133.

[9] G. Verstraeten, J. Poesen, The nature of small-scale flooding, muddy floods and retention pond sedimentation in central Belgium, Geomorphology 29 (1999) 275-292. 